\title{
Article \\ A Superhydrophobic, Antibacterial, and Durable Surface of Poplar Wood
}

\author{
Xinyu $W u^{1,2}{ }^{10}$, Feng Yang ${ }^{3}$, Jian Gan ${ }^{1,2}$, Zhangqian Kong ${ }^{1,2}$ and Yan $\mathrm{Wu}^{1,2, *}$ \\ 1 Department of Wood Products Engineering, College of Furnishings and Industrial Design, Nanjing Forestry \\ University, Nanjing 210037, China; wuxinyu@njfu.edu.cn (X.W.); agumpJ@njfu.edu.cn (J.G.); \\ kongzhangqian@njfu.edu.cn (Z.K.) \\ 2 Co-Innovation Center of Efficient Processing and Utilization of Forest Resources, Nanjing Forestry University, \\ Nanjing 210037, China \\ 3 Beijing Institute of Fashion Technology, Fashion Accessory Art and Engineering College, \\ Beijing 100029, China; yangfeng@bift.edu.cn \\ * Correspondence: wuyan@njfu.edu.cn
}

check for updates

Citation: Wu, X.; Yang, F.; Gan, J.;

Kong, Z.; Wu, Y. A

Superhydrophobic, Antibacterial, and Durable Surface of Poplar Wood.

Nanomaterials 2021, 11, 1885. https:// doi.org/10.3390/nano11081885

Academic Editor: Sergei Kulinich

Received: 22 June 2021

Accepted: 22 July 2021

Published: 23 July 2021

Publisher's Note: MDPI stays neutral with regard to jurisdictional claims in published maps and institutional affiliations.

Copyright: (c) 2021 by the authors. Licensee MDPI, Basel, Switzerland. This article is an open access article distributed under the terms and conditions of the Creative Commons Attribution (CC BY) license (https:/ / creativecommons.org/licenses/by/ $4.0 /)$.

\begin{abstract}
The silver particles were grown in situ on the surface of wood by the silver mirror method and modified with stearic acid to acquire a surface with superhydrophobic and antibacterial properties. Fourier transform infrared spectroscopy (FTIR), X-ray diffraction (XRD), and X-ray energy spectroscopy (XPS) were used to analyze the reaction mechanism of the modification process. Scanning electron microscopy (SEM) and contact angle tests were used to characterize the wettability and surface morphology. A coating with a micro rough structure was successfully constructed by the modification of stearic acid, which imparted superhydrophobicity and antibacterial activity to poplar wood. The stability tests were performed to discuss the stability of its hydrophobic performance. The results showed that it has good mechanical properties, acid and alkali resistance, and UV stability. The durability tests demonstrated that the coating has the function of water resistance and fouling resistance and can maintain the stability of its hydrophobic properties under different temperatures of heat treatment.
\end{abstract}

Keywords: superhydrophobicity; wood modification; antimicrobial properties; durability

\section{Introduction}

As a natural material, wood is one of the most important materials for structural construction, furniture, energy, and aerospace industries [1]. However, the negative characteristics of wood, such as water absorption, UV degradation, and poor resistance to microbial action, have limited the application of wood [2,3]. Therefore, special treatment of the wood surface to obtain hydrophobicity is necessary to prolong the service life of wood and give greater application to the value of wood [4-9].

Because superhydrophobic materials have special wettability [10], it is widely used in the fields of self-cleaning [11,12], antifouling [13], antisepsis [14,15], and oil-water separation [16,17]. The methods of preparing superhydrophobic wood include the etching method [18], the vapor deposition method [19], and the layer-by-layer self-assembly method [20]. When water droplets contact the surface, an air pad will be formed in the groove of the micro-nano rough structure on the superhydrophobic surface. Thus, a solidliquid-gas three-phase interface is formed, and the contact surface between water droplets and the surface is increased to prevent water droplets from infiltrating the surface [21-23]. Superhydrophobic surfaces are usually obtained in two steps: the first is to use nanoparticles such as $\mathrm{ZnO}$ [24], $\mathrm{SiO}_{2}$ [19], $\mathrm{TiO}_{2}$ [25], and $\mathrm{CaCO}_{3}$ to generate rough structures on the surface of the medium [26,27]; the second is to modify a rough surface with a low-surface energy substance $[28,29]$. At present, it is more common to attach nanoparticles to the wood surface by polymer and treat them with the substrate of low surface energy; however, due 
to the low adhesion between nanoparticles and wood, superhydrophobic wood often has poor mechanical properties. To improve the bonding force between interfaces and enhance the mechanical wear resistance of the wood surface, nanoparticles can be generated in situ on the wood surface through chemical reactions $[13,30]$. At the same time, considering that wood contains cellulose, hemicellulose, lignin, starch, sugar, and other components, it is a hotbed for microbial growth $[31,32]$. When the temperature and humidity and other environmental conditions are appropriate, these microorganisms will attach to the wood for a large number of growth and reproduction, resulting in wood decay, discoloration, and moldy, which influence the strength, toughness, and permeability of wood [6,33-35]. It also poses a threat to the life and health of the users [36-38]. Therefore, antibacterial treatment of wood is needed to maintain the properties of wood and prevent the spread of disease [39].

At present, the preparation of antimicrobial wood methods includes siloxane antifouling coating, copolymer, polymer, and other methods to inhibit the growth of bacteria; however, these polymer-based materials are often easily removed from the wood, showing poor mechanical properties. Therefore, it is necessary to develop a wood coating with high mechanical durability and antimicrobial properties [40]. The organic-inorganic mixed coating prepared by the sol-gel method can substitute for polymer-based antimicrobial coating, which is usually prepared from metallic alkanes or functional alkanes as precursors. It has environmental benefits and ensures strong mechanical properties and antifouling performance [41,42]. Silver nanoparticles have a strong antibacterial effect, which is since silver ions can inhibit the synthesis of enzymes on the extra-mercaptan groups of proteins on the microbial membrane, and eventually lead to the death of cells [43]. At the same time, silver nanoparticles have a smaller particle size and larger specific surface area, so they can dissolve in solution and release silver ions, thus achieving stronger antibacterial properties [44]. In general, the physical and chemical properties of silver nanoparticles, such as size, shape, or surface characteristics, can be controlled by chemical substances such as polymer, metal-ion interaction, or various reducing agents to construct functional surfaces [45]. Duan [46] prepared the wood with superhydrophobic antibacterial properties by self-polymerization of dopamine and hydrophobic modification of copper nanoparticles on the surface of the wood with fluoro silane. The coating showed good resistance to acid or alkali corrosion and good mechanical properties. Gao [47] treated wood with sodium hydroxide and silver nitrate, then reduced nano-silver ions on the wood surface with glucose and modified with fluoro silane to prepare a kind of superhydrophobic and oil-phobic wood with electrical conductivity. These methods of preparation of superhydrophobic wood used the chemical reaction directly on the wood surface to grow nanoparticles, guarantee the superhydrophobic coating and the cohesive strength between wood, thus showed excellent mechanical properties. This method will be beneficial to expand the application forms of superhydrophobic wood, and has a high application value in the fields of self-cleaning, biomedicine, and electronic information.

Here, we successfully deposited silver particles on the wood surface through the reaction of silver ammonia solution and sodium hydroxide with a simple silver mirror reaction [48]. First, the poplar wood was pretreated with $\mathrm{NaOH}$ solution to make the surface of it negatively charged. It absorbed $\mathrm{Ag}\left(\mathrm{NH}_{3}\right)_{2}{ }^{+}$after being impregnated with a silver ammonia complex solution. $\mathrm{Ag}\left(\mathrm{NH}_{3}\right)_{2}{ }^{+}$was reduced to $\mathrm{Ag}$ particles in situ on the wood surface by formaldehyde reduction. After that, the treated wood was modified by stearic acid with a long-chain alkyl group [49] to obtain a superhydrophobic surface with a contact angle of $158.7^{\circ}$. The modified surface has waterproof, fouling, and antibacterial properties, and stable superhydrophobic properties under mechanical wear cycle, acid and alkali solution, ultraviolet light, and different temperatures of heat treatment. 


\section{Materials and Methods}

\subsection{Materials}

The poplar wood (Populus tomentosa) with $20 \mathrm{~mm}$ in length and width, $2 \mathrm{~mm}$ in thickness, was provided by Yixuan Material Co. Ltd., Dongguan, China. Its moisture content was $9.5 \%$ and the absolute dry density was $284.5 \mathrm{~kg} / \mathrm{m}^{3}$. Sodium hydroxide $(\mathrm{NaOH}$, $96 \%)$, ammonia $\left(\mathrm{NH}_{3} \cdot \mathrm{H}_{2} \mathrm{O}, 28 \%\right)$, acetic acid $\left(\mathrm{CH}_{3} \mathrm{COOH}, 99.5 \%\right)$ were purchased from Nanjing Chemical Reagent Co., Ltd., Nanjing, China. The silver nitrate solution $\left(\mathrm{AgNO}_{3}\right)$ was from Guangzhou Kyle Chemical Co., Ltd., Guangzhou, China. Formaldehyde solution $\left(\mathrm{CH}_{2} \mathrm{O}\right)$ was supplied by Shanghai Jiuyi Chemical Reagent Co., Ltd., Shanghai, China. The anhydrous ethanol (99.7\%) was from Sinopharm Chemical Reagent Co., Ltd., Shanghai, China, and the stearic acid $\left(\mathrm{C}_{18} \mathrm{H}_{36} \mathrm{O}_{2}\right)$ was from Tianjin Chemical Technology Co., Ltd., Tianjin, China.

\subsection{Methods}

The poplar wood used in this experiment was ultrasonically cleaned (Misonix, Inc., New York, NY, USA) in anhydrous ethanol for $30 \mathrm{~min}$ and distilled water for $30 \mathrm{~min}$ and dried at $60{ }^{\circ} \mathrm{C}$ in a constant temperature blast drying oven (Shangchen Instrument Co., Ltd., Shaoxin, China). Then the dried wood was impregnated in sodium hydroxide solution with a concentration of $0.1 \mathrm{M}$ for $12 \mathrm{~h}$. After taking it out, the poplar was cleaned by ultrasound with distilled water for $15 \mathrm{~min}$ and dried at room temperature. Then $0.1 \mathrm{M}$ silver nitrate and sodium hydroxide solution was arranged in a three-mouth flask. After mixing, ammonia water was added drop by drop, and it was constantly stirred until the solution becomes clear and transparent. The wood was impregnated in the solution of silver ammonia for one hour and then a certain amount of formaldehyde solution was added and stirred in the DF-101Z magnetic stirrer (Lichen Scientific Instrument Factory, Shanghai, China) with a constant temperature at $6^{\circ} \mathrm{C}$ for $15 \mathrm{~min}$ to prepare the wood coated with silver (wood@Ag). After extraction, it was dried at $120{ }^{\circ} \mathrm{C}$ for $2 \mathrm{~h}$, then was immersed in the ethanol mixture of $30 \mathrm{~mL}$ stearic acid $(4 \mathrm{wt} \%)$ and acetic acid $(0.08 \mathrm{M})$. After $4 \mathrm{~min}$, it was taken out and dried at room temperature to obtain the poplar wood with the silver grafted with stearic acid (wood@Ag@SA).

\subsection{Analysis of Reaction Mechanism}

Vertex $80 \mathrm{~V}$ Fourier Transform Infrared Spectrometer (Brock Spectral Instruments $\mathrm{GmbH}$, Karlsruhe, Germany) was used to analyze the chemical composition on the surface of the wood sample loaded with Ag (wood@Ag) and after modification of the stearic acid (wood@Ag@SA), with the wavenumber of 500-4000 cm $\mathrm{cm}^{-1}$. The surface chemical composition of wood@Ag and wood@Ag@SA, over the range of $30^{\circ}-80^{\circ}$, was characterized by Axis Ultradld XRD (Rigaku Corporation, Osaka, Japan). The element composition and content of wood@Ag and wood@Ag@SA were characterized by Axis Ultradld XPS (Nippon Koji Co. Ltd., Tokyo, Japan). The scanning mode was CAE, and the spectrum was calibrated with the reference voltage of C $1 \mathrm{~s}=284.6 \mathrm{eV}$.

\subsection{Surface Morphology and Wettability Analysis}

A small piece of wood@Ag and wood@Ag@SA were pasted on the observation platform through the conductive adhesive and sprayed with gold. The surface morphology was observed under vacuum by Quanta 200 environmental scanning electron microscopy (FEI Corporation, New York, NY, USA) (Hong, Sunghwan). The water contact angles (WCAs) of wood@Ag@SA were measured by the Theta T200 optical contact Angle analyzer (Biolin Technologies GmbH, Gothenburg, Sweden). The droplet volume was $6 \mu \mathrm{L}$. The test was repeated three times on the surface of each sample to achieve the average value. Then, the water bouncing test was conducted and recorded, which is the process having droplets of water fall onto the contact surface until it left the surface. 


\subsection{Antimicrobial Test}

The antibacterial activity of wood@Ag@SA was qualitatively evaluated by Staphylococcus aureus (ATCC 2592, Gram-positive) [50]. First, the nutrient agar was dissolved together with the nutrient broth in deionized water with a $\mathrm{pH}$ of 7 . The mixture was then autoclaved with an empty petri dish at $121^{\circ} \mathrm{C}$ for $30 \mathrm{~min}$. The obtained agar medium was separated and cooled in laminar flow. Then 3,300,000 CFU/mL of bacteria were covered on the Petri dishes. Finally, the wood samples were placed in Petri dishes and cultured at $37^{\circ} \mathrm{C}$ for $24 \mathrm{~h}$. The bacterial colony count method was used to calculate according to Formula (1)

$$
R=\frac{\left(T_{0}-T_{1}\right)}{T_{0}} \times 100 \%
$$

where $T_{0}$ is the number of bacteria in the blank sample; $T_{1}$ is the number of bacteria in the plate of the tested sample. After 3 counts, the average value of the antibacterial rate $R$ was obtained.

\subsection{Stability Test}

In the mechanical wear resistance test, with the force of $150 \mathrm{~N}$, the surface of Ag@SA@wood was pressed by fingers, and then it experienced 50 times friction cycles at $9.8 \mathrm{KPa}$ pressure, using 2000 mesh sandpaper on the surface of $100 \mathrm{~cm}$ reciprocating friction. It was continued to be scratched with a knife on the surface to form grid marks, with the distance between two adjacent marks around 2 mm [51]. Finally, the WCAs of wood@Ag@SA after the mechanical wear resistance test were recorded. It was impregnated in solutions after immersion in $\mathrm{HCl}$ solution $(\mathrm{pH}=1)$ and $\mathrm{NaOH}$ solution $(\mathrm{pH}=12)$ for $24 \mathrm{~h}$, then it was washed with distilled water and dried at $85{ }^{\circ} \mathrm{C}$ to measure the WCAs of the surface. To test the UV stability of wood@Ag@SA, it was exposed to a $365 \mathrm{~nm}$ UV lamp for $6 \mathrm{~h}$, and the wettability of its surface was tested.

\subsection{Contaminant Resistance Test and Durability Testing}

Common daily liquids such as tea, milk, coffee, and orange juice were dropped on the surface of wood@Ag@SA with a syringe to test its performance of antifouling [52]. To determine the water resistance of wood@Ag@SA, the original poplar wood and wood @Ag@SA were impregnated in deionized water and placed at room temperature for a while. The samples were taken out and dried at $85^{\circ} \mathrm{C}$ for $1 \mathrm{~h}$ to record their weight every 5 days. The water absorption of the samples before and after modification was calculated by the formula (2)

$$
\mathrm{WA}(\%)=\left(m_{a i}-m_{b i}\right) / m_{b i} \times 100 \%
$$

where $m_{a i}$ is the weight after water absorption and $m_{b i}$ is the weight of dry wood. To discuss the heat resistance of wood@Ag@SA, it was kept in a constant temperature blast drying oven at the temperature of $20{ }^{\circ} \mathrm{C}, 40^{\circ} \mathrm{C}, 60^{\circ} \mathrm{C}, 80^{\circ} \mathrm{C}, 80^{\circ} \mathrm{C}$, and $120^{\circ} \mathrm{C}$, for six hours, respectively, and the WCAs of it were tested.

\section{Results}

\subsection{Analysis of Reaction Mechanism \\ 3.1.1. FTIR and XRD}

Figure 1a shows the infrared spectra of wood@Ag and wood@Ag@SA, in which the bending vibration of $-\mathrm{CH}_{3}\left(-\mathrm{CH}_{2}-\right)$ was at $1456.6 \mathrm{~cm}^{1,}$ and the peak at $2841.8 \mathrm{~cm}^{-1}$ and $2914.5 \mathrm{~cm}^{1}$ was the stretching vibration of $-\mathrm{CH}_{3}\left(-\mathrm{CH}_{2}-\right)$. It showed that the stearic acid had successfully modified wood@Ag. The vibration absorption peak of Ag-O appeared at $663.6 \mathrm{~cm}^{-1}$. The peak from $1020.8 \mathrm{~cm}^{-1}$ to $1120.1 \mathrm{~cm}^{-1}$ corresponded to the asymmetric stretching vibration peak of $\mathrm{C}-\mathrm{O}$ in the $\mathrm{CH}_{3}\left(\mathrm{CH}_{2}\right)_{16} \mathrm{COO}$ - group. The absorption peak attributed to -COO- appeared at $1580-1620 \mathrm{~cm}^{-1}$, indicating that $-\mathrm{COOH}$ of stearic acid reacted chemically with $\mathrm{Ag}^{+}$of wood@Ag to generate the -COOAg group. To effectively understand the chemical composition of wood@Ag and wood@Ag@SA, the crystal composition of the coating surface was tested by XRD. The results are shown in Figure 1b. The 
main peaks were $38.1^{\circ}, 44.2^{\circ}, 64.4^{\circ}$, and $77.4^{\circ}$, respectively. Therefore, it can be concluded that the main composition of the coating surface of wood@Ag and wood@Ag@SA was Ag. The results reflected that the purity of Ag on the surface of wood@Ag@SA was low and the crystallinity was poor.
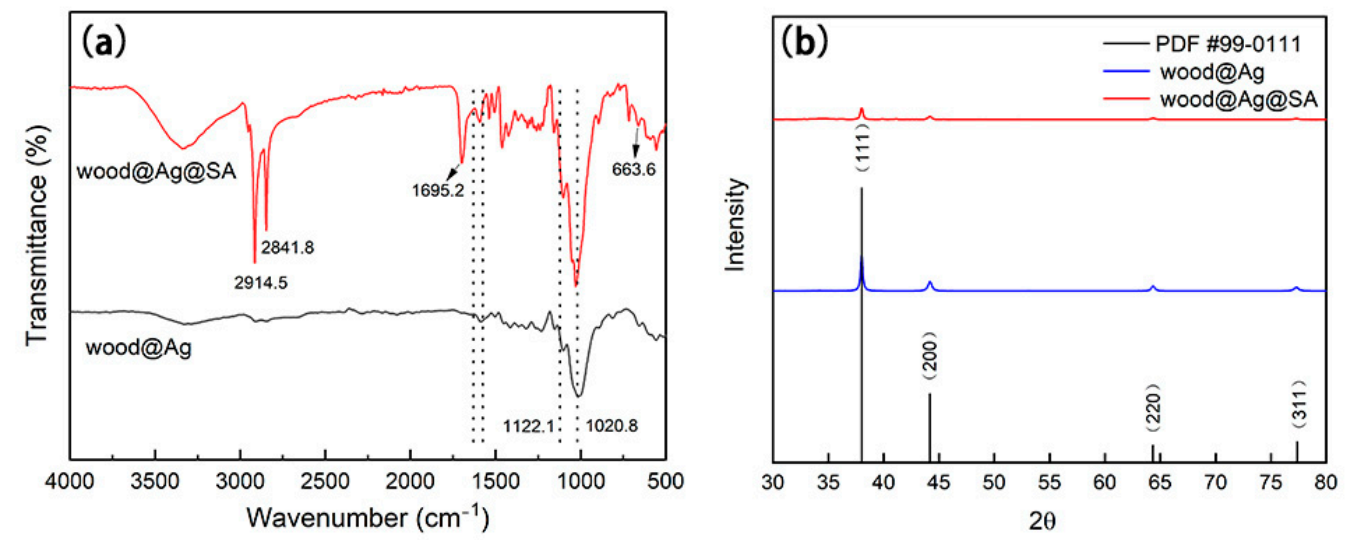

Figure 1. The infrared spectra (a) and X-ray diffraction spectra (b) of wood@Ag and wood@Ag@SA.

\subsubsection{XPS}

Figure 2 shows the XPS spectra of wood@Ag and wood@Ag@SA. The main elements were carbon, oxygen, and silver. As shown in Figure 2c, the peak at $284.7 \mathrm{eV}$ belonged to $\mathrm{C}-\mathrm{C}$ in stearic acid molecules, the peak at $285.8 \mathrm{eV}$ was $\mathrm{C}-\mathrm{O}$, and the peak at $288.5 \mathrm{eV}$ corresponded to $\mathrm{C}=\mathrm{O}$ [53]. In Figure $2 \mathrm{~g}$, the peak at $286.1 \mathrm{eV}$ belonged to $\mathrm{C}-\mathrm{O}$ and the peak at $284.7 \mathrm{eV}$ was distributed as C-C. After the modification of stearic acid, the surface of wood@Ag@SA had higher carbon content, lower oxygen content, and lower silver content. The carbon content of it increased from $56.62 \%$ to $66.63 \%$, whereas the oxygen content decreased from $19.77 \%$ to $12.8 \%$.
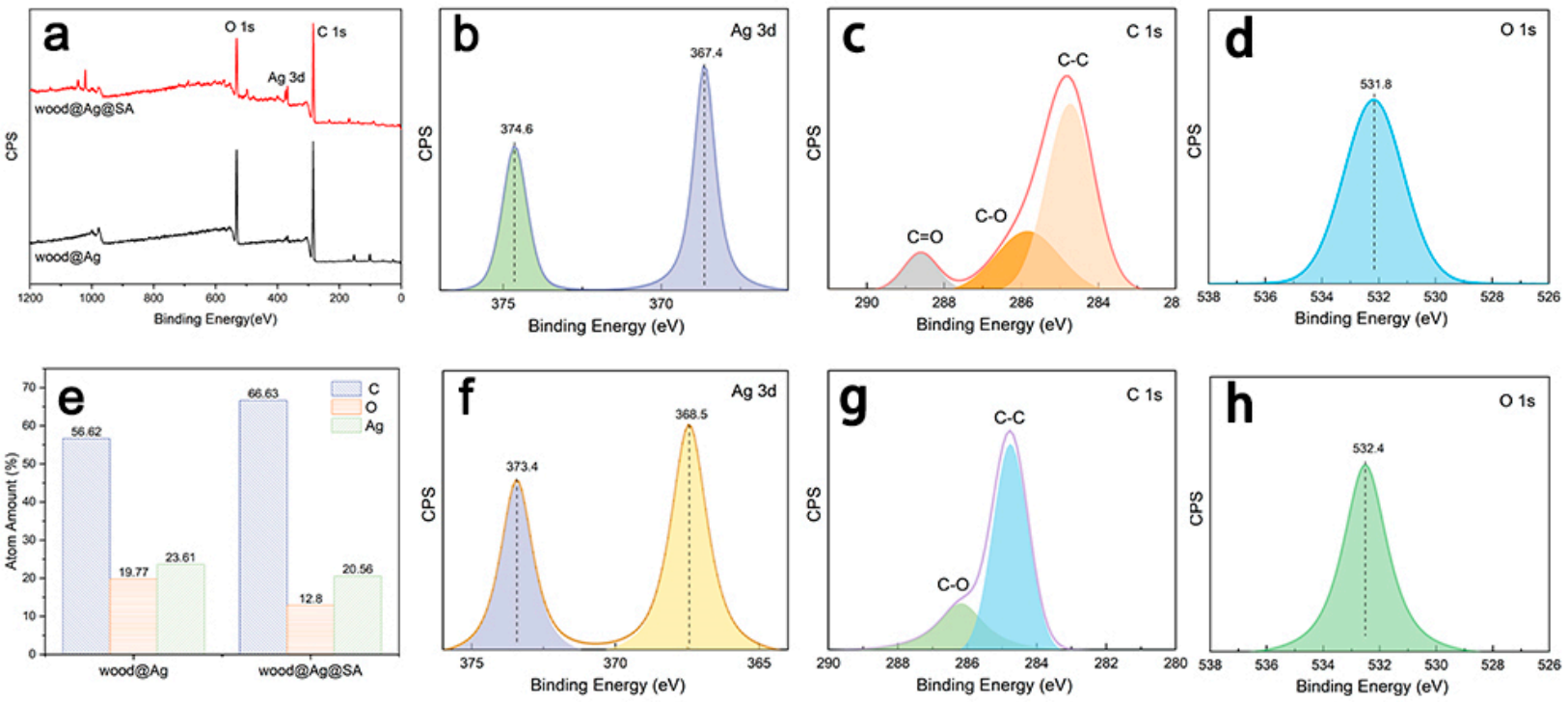

Figure 2. (a) The XPS survey of wood@Ag and wood@Ag@SA; (b) Ag 3d XPS spectra of wood@Ag; (c) C 1s XPS spectra of wood @Ag; (d) O 1s spectra of wood@Ag; (e) the atom amount distribution of wood@Ag and wood@Ag@SA; (f) Ag 3d XPS spectra of wood@Ag@SA; (g)C 1s XPS spectra of wood @Ag@SA; (h) O 1s spectra of wood@Ag@SA.

\subsubsection{Analysis of Modification Mechanism}

Figure 3 reveals the modification mechanism of wood@Ag@SA. The pretreatment of sodium hydroxide formed $\mathrm{OH}^{-}$on the wood surface. A mixture of sodium hydroxide and 
silver nitrate reacted with ammonia to form a solution of silver ammonia. Then, the wood absorbed $\mathrm{Ag}\left(\mathrm{NH}_{3}\right)_{2}{ }^{+}$after being impregnated with the silver ammonia complex solution. Through the reduction of formaldehyde, $\mathrm{Ag}\left(\mathrm{NH}_{3}\right)_{2}{ }^{+}$was reduced to $\mathrm{Ag}$ particles on the wood surface. Stearic acid acts as an amphiphilic ligand in the synthesis of Ag@SA because it has a carboxylic acid head group bound to the surface of $\mathrm{Ag}^{+}$and a hydrophobic alkyl chain tail facing the external medium. Under the catalysis of acetic acid, the carboxylic acid of stearic acid reacted with silver ions, the $\mathrm{H}^{+}$of $-\mathrm{COOH}$ was replaced by silver ions, and the hydrophobic group $-\mathrm{CH}_{3}$ with low surface energy was introduced on the surface of silver particles.
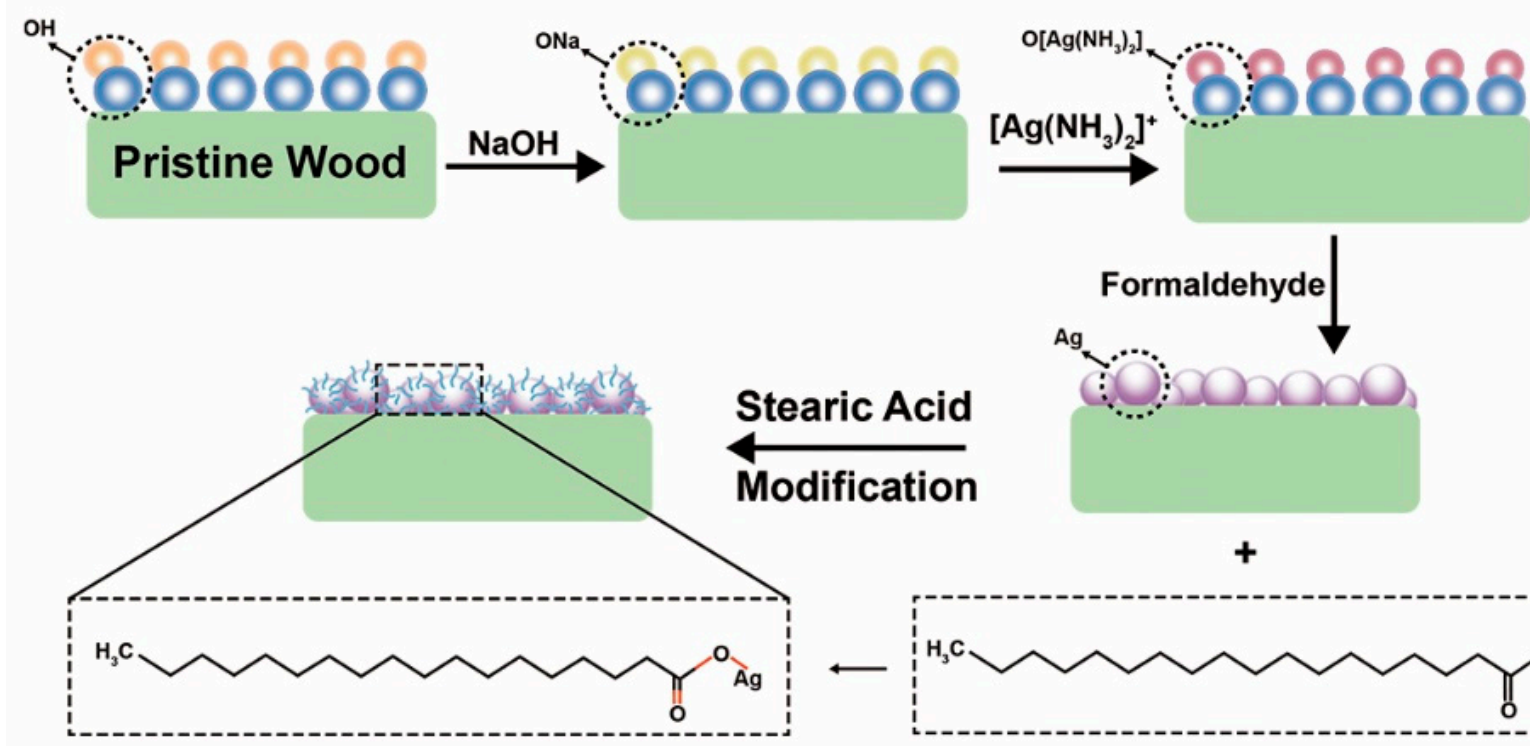

\section{Stearic Acid Modification}
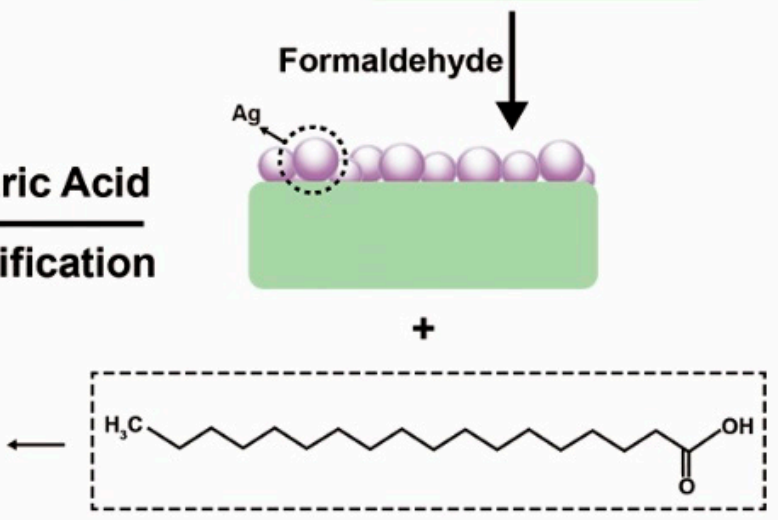

Figure 3. The modification mechanism of wood@Ag@SA.

\subsection{Surface Morphology and Wettability Analysis}

Figure 4 reveals the surface morphology and wettability of wood@Ag@SA. As shown in Figure $4 \mathrm{a}$, the fibers on the surface of poplar wood were uniformly loaded with a layer of Ag particles. As can be seen in Figure 4b, the Ag particles were spherical on the surface of the fibers of poplar wood, forming a rough structure. It can be observed in Figure 4c that after modification, the long-chain hydrophobic alkyl in the stearic acid molecule was successfully grafted to the wood surface. It can be observed from Figure $4 \mathrm{~d}$ that the surface of the coating was distributed with coral-like papillae with a slender root connecting the dense particles to the matrix. This grooved structure avoided the agglomeration phenomenon between particles. Meanwhile, the introduction of long hydrophobic alkyl chains reduced the surface energy of the coating [54]. It can be observed in Figure 4e that the main elements on the surface of wood@Ag@SA were C, O, and Ag. Figure 4f is the test diagram of the contact angle between the surface and water wood@Ag@SA. The contact angle of water on the surface was $158.7^{\circ}$. The water droplets completely leave the surface without wetting, indicating that the surfaces were superhydrophobic. This was because the methyl-grafted silver particles form an air cushion between the coating and the water droplets, thus decreasing the contact area between the coating and the water drop, and achieving the superhydrophobic performance of wood@Ag@SA. The result of the water bouncing test was shown in Figure $4 \mathrm{~g}$. The process of droplets dropping from the beginning to the contact surface until they leave the surface shows the low viscoelasticity of water droplets and the surface [55]. 

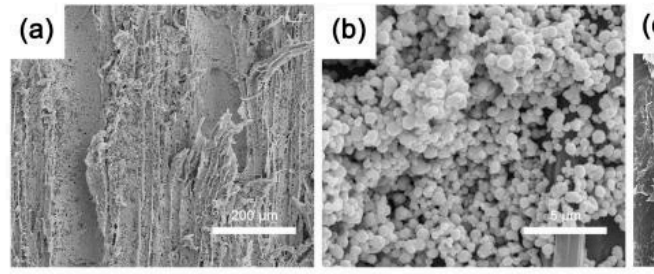

(f)
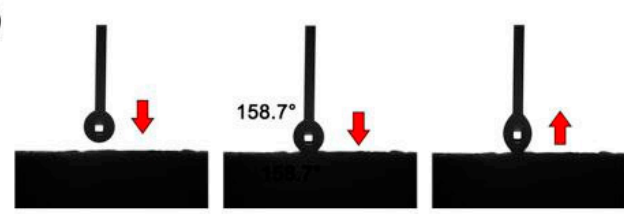

(c)
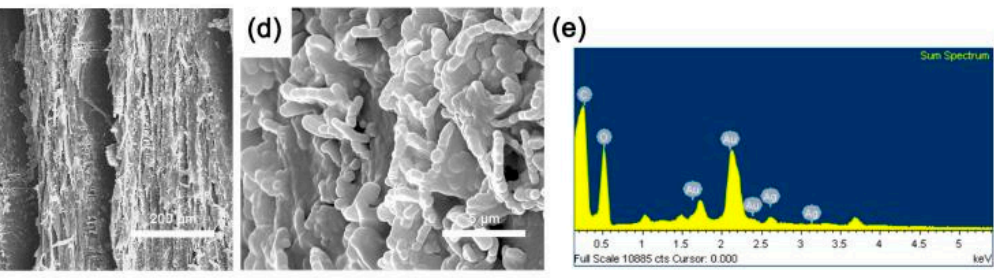

(g)

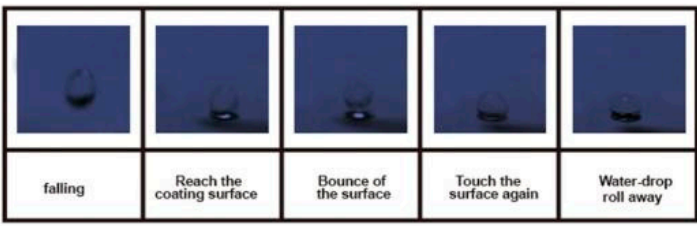

Figure 4. (a) SEM images of wood@Ag at 200 magnification; (b) SEM images of wood@Ag at 8000 magnification; (c) SEM images of wood@Ag@SA at 200 magnification; (d) SEM images of wood@Ag@SA at 8000 magnification and wood@Ag@SA; (e) EDS images of wood@Ag@SA; (f) WCA test of wood@Ag@SA; (g) water bouncing test of wood@Ag@SA.

\subsection{Antimicrobial Test}

As shown in Table 1, colony analysis was carried out on wood and liquefied wood to calculate the colony formation unit (CFU) [56]. It showed that the antimicrobial rate of wood@Ag@SA to Staphylococcus aureus could reach 99.9\%, indicating that wood@Ag@SA has a good antibacterial effect. The antibacterial mechanism of the coating is introduced in Figure 5, showing the atomic arrangement and particle structure on the surface of wood@Ag@SA. The core of the particles was a silver atom, and the outer was a silver ion. Some of $\mathrm{Ag}^{+}$grafted with hydrophobic alkyl, and the other part was free. The antibacterial properties of wood@Ag@SA were realized through its superhydrophobic properties and the antibacterial properties of $\mathrm{Ag}^{+}$. On the one hand, the superhydrophobicity of wood@Ag@SA can reduce the contact area between the coating and the bacterial solution, thus realizing the bacteriostatic effect. On the other hand, the $\mathrm{Ag}^{+}$on the surface of wood@Ag@SA had a strong oxidation capacity, which could destroy the protein, lipid, and DNA of the cell through the catalytic effect of the cell enzyme, so that the cell produced metabolic disorders, thus losing activity. The silver ions on the surface of wood@Ag@SA could also bind with enzymes in donor sulfhydryl groups to release other ions in the cell, thus making it difficult for cellular enzymes to play their roles and causing bacterial inactivation [57].

Table 1. The antimicrobial test of wood@Ag@SA.

\begin{tabular}{ccc}
\hline Name of the Sample & Colony Forming Unit (CFU) & Antimicrobial Rate of Staphylococcus Aureus (\%) \\
\hline wood@Ag@SA & 500 & 99.9 \\
\hline
\end{tabular}

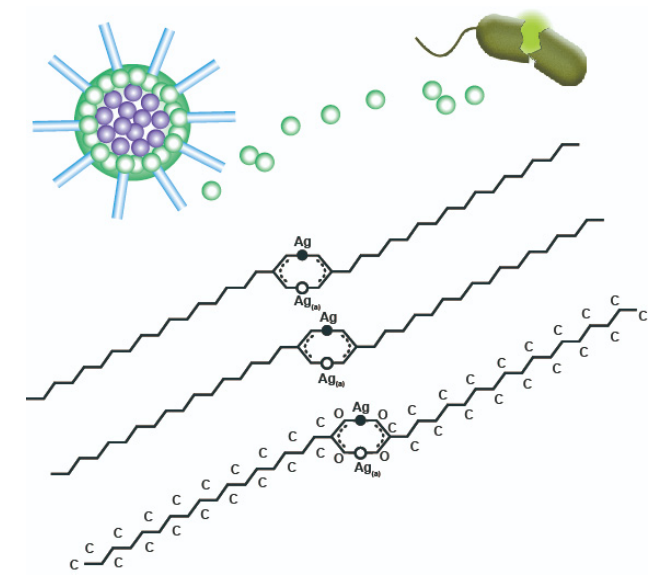

Figure 5. The antimicrobial mechanism of wood@Ag@SA. 


\subsection{Stability Test}

As shown in Figure 6a, the contact angle of wood@Ag@SA was $153.6^{\circ}$ after the mechanical wear resistance test. This was because the pretreatment of sodium hydroxide made the surface of wood be negatively charged and firmly combined with the Ag particles generated by the reaction of the silver mirror. It made the rough structures and low-surface substances on the surface of the wood remain stable after repeated friction or cutting, giving the coating strong mechanical stability [58]. Figure 6b shows the WCAs of wood@Ag@SA during the acid and alkali resistance test. After $500 \mathrm{~h}$ of impregnation in acidic solution, the WCA of it was $154.2^{\circ}$, and after $500 \mathrm{~h}$ of impregnation in alkaline solution, the WCAs was $152.5^{\circ}$, indicating that wood@Ag@SA has the certain corrosion resistance of acid and alkali solution. The prepared wood@Ag@SA also had a certain ability to resist ultraviolet radiation. In Figure 6c, after the coating was irradiated under the UV lamp for $72 \mathrm{~h}$, the water droplets remain spherical on the surface of the sample. The test showed that the WCA of it is $156.8^{\circ}$, which proved that wood@Ag@SA has certain UV stability [59]. This was because the organic-inorganic hybrid process has generated $-\mathrm{CH}_{3}$ on the surface of wood@Ag@SA, which has certain stability and was difficult to degrade under ultraviolet radiation, so the low surface energy of the surface can be maintained.
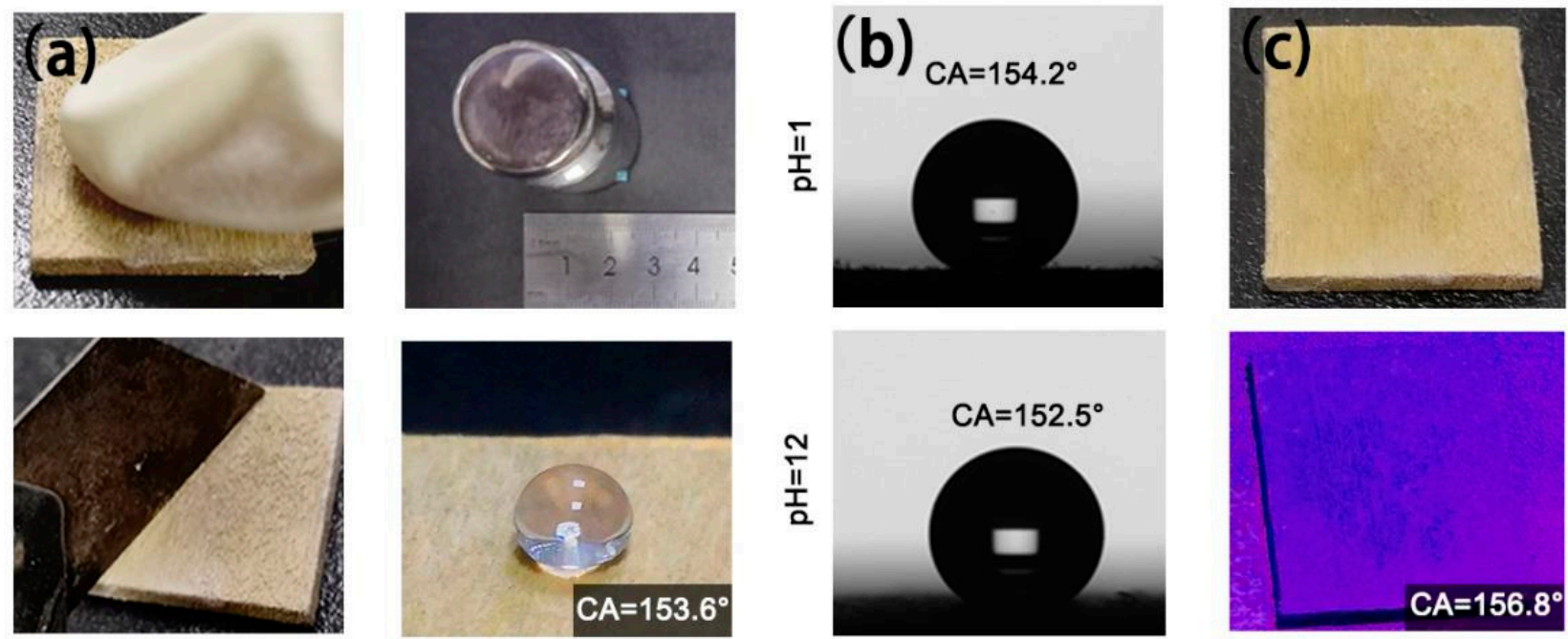

Figure 6. The WCAs of wood@Ag@SA after the mechanical wear resistance test (a) and after immersion in $\mathrm{HCl}$ solution $(\mathrm{pH}=1)$ and $\mathrm{NaOH}$ solution $(\mathrm{pH}=12)(\mathbf{b})$, and after exposure to a $365 \mathrm{~nm} \mathrm{UV} \mathrm{lamp} \mathrm{for} 6 \mathrm{~h}(\mathbf{c})$.

\subsection{Contaminant Resistance Test and Durability Test}

Figure 7a shows the contaminant resistance test of wood@Ag@SA, which shows that common domestic contaminants did not leave traces on the surface due to a certain water repellency of the surface. Figure $7 \mathrm{~b}$ shows that with the increase of immersion days, the water absorption of wood and wood@Ag@SA shows an upward trend, while the water absorption of wood@Ag@SA was always lower than that of wood. When the immersion days were less than 30 days, the water absorption rate of wood@Ag@SA was almost constant. When the immersion days increased to 50 days, the water absorption of wood reached $77.2 \%$, while wood@Ag@SA was 54.8\%, which still maintained a low water absorption level. This indicated that the water repellant of wood@Ag@SA inhibited its absorption of water, thus reducing the possibility of shrinkage deformation and mildew in the moisture environment. It can be seen from Figure 7c that wood@Ag@SA can still maintain superhydrophobicity after treatment at various temperatures. After treatment at $120^{\circ} \mathrm{C}$ for $6 \mathrm{~h}$, the WCA on the surface of wood@Ag@SA was $152.4^{\circ}$, which proved that it has good heat resistance [25,60-62]. 
(a)

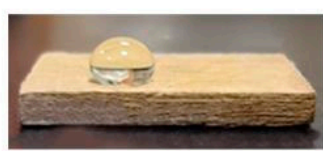

tea

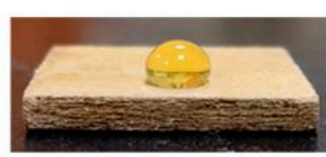

juice

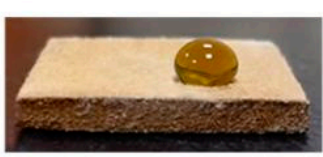

coffee

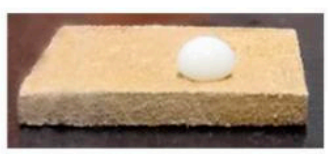

milk (b)

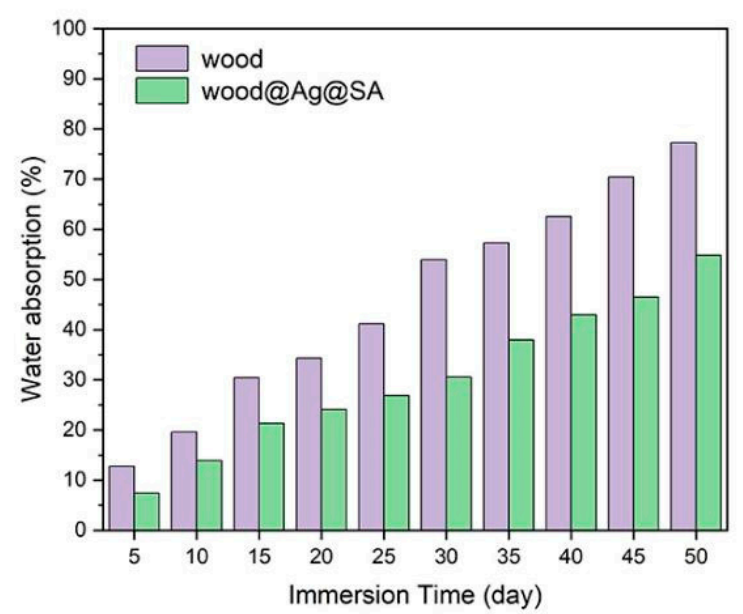

(c)

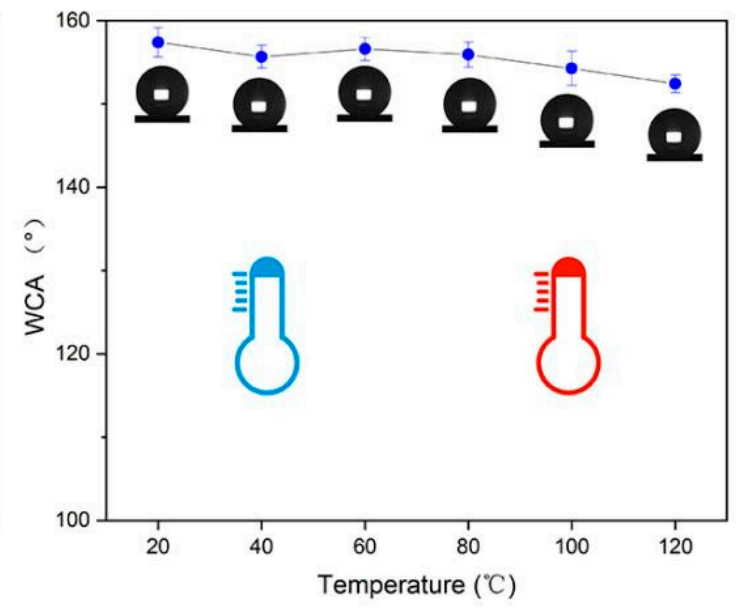

Figure 7. The images of different contaminants on the wood@Ag@SA (a)Changes of water adsorption for wood@Ag@SA as a function of time after immersion in water; $(\mathbf{b})$ changes of WCA for wood@Ag@SA as a function of time after being treated in a constant temperature blast drying oven at the temperature of $20^{\circ} \mathrm{C}, 40^{\circ} \mathrm{C}, 60^{\circ} \mathrm{C}, 80^{\circ} \mathrm{C}, 80^{\circ} \mathrm{C}$, and $120^{\circ} \mathrm{C}$ for six hours (c).

\section{Conclusions}

In this experiment, a convenient and effective method for preparing superhydrophobic and antimicrobial wood was proposed by the organic-inorganic mixing method. The Ag particles were prepared on a wood surface with the disposal of a silver ammonia complex solution and then reduced with formaldehyde. The Ag particles were coated with low surface energy stearic acid and further modified to obtain a superhydrophobic surface with a WCA of $158.7^{\circ}$. The formation mechanism and antimicrobial mechanism of the rough structure were analyzed. The surface morphology was characterized, and the stability test was carried out. The mechanical wear resistance, UV resistance, and acid and alkali resistance of wood@Ag@SA were tested. The results showed that it could maintain the superhydrophobic property in a harsh environment. The antifouling and water absorption tests showed that the modified wood was waterproof and fouling resistant. The poplar wood coating showed excellent properties in hydrophobicity, antimicrobial property, and durability, making it suitable for self-cleaning and biomedical applications.

Author Contributions: Conceptualization, X.W.; data curation, Y.W. and J.G.; funding acquisition, Y.W., F.Y.; methodology, X.W.; resources, F.Y.; writing—original draft, X.W.; writing—review and editing, Y.W. and Z.K. All authors have read and agreed to the published version of the manuscript.

Funding: This research was funded by the National Natural Science Foundation of China (32071687 and 32001382), the Project of Science and Technology Plan of Beijing Municipal Education Commission (KM202010012001), and the Special Scientific Research Fund of Construction of High-level Teachers Project of the Beijing Institute of Fashion Technology (BIFTQG201805).

Institutional Review Board Statement: Not applicable.

Informed Consent Statement: Not applicable.

Data Availability Statement: Not applicable. 
Acknowledgments: The authors gratefully acknowledge the financial support from the project funded by the National Natural Science Foundation of China (32071687 and 32001382), the Project of Science and Technology Plan of Beijing Municipal Education Commission (KM202010012001), and the Special Scientific Research Fund of Construction of High-level teachers Project of Beijing Institute of Fashion Technology (BIFTQG201805).

Conflicts of Interest: The authors declare no conflict of interest.

\section{References}

1. Spear, M.J.; Curling, S.F.; Dimitriou, A.; Ormondroyd, G.A. Review of Functional Treatments for Modified Wood. Coatings 2021, 11, 327. [CrossRef]

2. Liu, X.; Timar, M.C.; Varodi, A.M. A comparative study on the artificial UV and natural ageing of beeswax and Chinese wax and influence of wax finishing on the ageing of Chinese Ash (Fraxinus mandshurica) wood surfaces. J. Photochem. Photobiol. B-Biol. 2019, 201. [CrossRef] [PubMed]

3. Li, R.; Fang, L.; Xu, W.; Xiong, X.; Wang, X. Effect of Laser Irradiation on the Surface Wettability of Poplar Wood. Sci. Adv. Mater 2019, 11, 655-660. [CrossRef]

4. Janesch, J.; Arminger, B.; Gindl-Altmutter, W.; Hansmann, C. Superhydrophobic coatings on wood made of plant oil and natural wax. Prog. Org. Coat. 2020, 148. [CrossRef]

5. Zhan, K.; Lu, Q.; Xia, S.; Guo, C.; Zhao, S.; Gao, W.; Yang, L.; Morrell, J.J.; Yi, T.; Xie, L.; et al. A cost effective strategy to fabricate STA@PF@ $\mathrm{Cu}_{2} \mathrm{O}$ hierarchical structure on wood surface: Aimed at superhydrophobic modification. Wood Sci. Technol. 2021, 55, 565-583. [CrossRef]

6. Yang, R.; Zuo, S.; Song, B.; Mao, H.; Huang, Z.; Wu, Y.; Cai, L.; Ge, S.; Lian, H.; Xia, C. Hollow Mesoporous Microspheres Coating for Super-Hydrophobicity Wood with High Thermostability and Abrasion Performance. Polymers 2020, 12, 2856. [CrossRef]

7. Feng, X.; Wu, Z.; Sang, R.; Wang, F.; Zhu, Y.; Wu, M. Surface Design of Wood-Based Board to Imitate Wood Texture Using 3D Printing Technology. Bioresources 2019, 14, 8196-8211. [CrossRef]

8. Huang, C.; Dong, H.; Zhang, Z.; Bian, H.; Yong, Q. Procuring the nano-scale lignin in prehydrolyzate as ingredient to prepare cellulose nanofibril composite film with multiple functions. Cellulose 2020, 27, 9355-9370. [CrossRef]

9. Zheng, Y.; Yu, Y.; Lin, W.; Jin, Y.; Huang, C. Enhancing the enzymatic digestibility of bamboo residues by biphasic phenoxyethanolacid pretreatment. J. Bioresour. Technol. 2021, 325, 124691. [CrossRef]

10. Deng, Y.; Mager, D.; Bai, Y.; Zhou, T.; Liu, Z.; Wen, L.; Wu, Y.; Korvink, J.G. Inversely designed micro-textures for robust Cassie-Baxter mode of super-hydrophobicity. Comput. Methods Appl. Mech. Eng. 2018, 341, 113-132. [CrossRef]

11. Lu, Z.; Xu, L.; He, Y.; Zhou, J. One-step facile route to fabricate functionalized nano-silica and silicone sealant based transparent superhydrophobic coating. Thin Solid Film. 2019, 692. [CrossRef]

12. Zhang, W.; Jiang, S.; Lv, D. Fabrication and characterization of a PDMS modified polyurethane/Al composite coating with super-hydrophobicity and low infrared emissivity. Prog. Org. Coat. 2020, 143. [CrossRef]

13. Zhang, Y.; Zhang, Y.; Cao, Q.; Wang, C.; Yang, C.; Li, Y.; Zhou, J. Novel porous oil-water separation material with superhydrophobicity and super-oleophilicity prepared from beeswax, lignin, and cotton. Sci. Total Environ. 2020, 706. [CrossRef] [PubMed]

14. Zhang, M.; Zhao, W.; Zhang, X.; Li, Z.; Yu, L.; Li, X.; Zhang, Z. Nonfluoride-modified halloysite nanotube-based hybrid: Potential for acquiring super-hydrophobicity and improving flame retardancy of epoxy resin. J. Nanostructure Chem. 2021. [CrossRef]

15. Jin, C.; Li, J.; Han, S.; Wang, J.; Sun, Q. A durable, superhydrophobic, superoleophobic and corrosion-resistant coating with rose-like ZnO nanoflowers on a bamboo surface. Appl. Surf. Sci. 2014, 320, 322-327. [CrossRef]

16. Ma, T.; Li, L.; Mei, C.; Wang, Q.; Guo, C. Construction of sustainable, fireproof and superhydrophobic wood template for efficient oil/water separation. J. Mater. Sci. 2021, 56, 5624-5636. [CrossRef]

17. Zhang, D.; Jin, X.-Z.; Huang, T.; Zhang, N.; Qi, X.-D.; Yang, J.-H.; Zhou, Z.-W.; Wang, Y. Electrospun Fibrous Membranes with Dual-Scaled Porous Structure: Super Hydrophobicity, Super Lipophilicity, Excellent Water Adhesion, and Anti-Icing for Highly Efficient Oil Adsorption/Separation. Acs. Appl. Mater. Interfaces 2019, 11, 5073-5083. [CrossRef]

18. Gregorcic, P.; Conradi, M.; Hribar, L.; Hocevar, M. Long-Term Influence of Laser-Processing Parameters on (Super)hydrophobicity Development and Stability of Stainless-Steel Surfaces. Materials 2018, 11, 2240. [CrossRef]

19. Kundu, D.; Banerjee, D.; Ghosh, S.; Tewari, R.C.; Das, N.S.; Das, B.; Chattopadhyay, K.K. Achievement of nearly super hydrophobicity in plasma enhanced chemical vapour deposited one and two dimensional carbon nanostructures. Phys. E-LowDimens. Syst. Nanostruct. 2019, 108, 7-14. [CrossRef]

20. Wen, Y.; Kong, D.; Shang, W.; Ma, M.; Jiang, J.; Li, J.; Peng, N. Effect of bis-(3-triethoxysilylpropyl)-tetrasulfide on SuperHydrophobicity and Corrosion Resistance of Self-Assembled Monolayers on 6061 Aluminum Alloys. Int. J. Electrochem. Sci. 2019, 14, 6018-6031. [CrossRef]

21. Gong, W.; Wang, Y.; Chen, Y.; Li, X.; Li, K.; Wang, Z.; Yan, Y. A Study of the Truncated Square Pyramid Geometry for Enhancement of Super-hydrophobicity. J. Bionic Eng. 2020, 17, 843-850. [CrossRef]

22. Wang, N.; Wang, Q.; Xu, S.; Zheng, X. Fabrication of multifunctional amphiphobic surfaces on copper substrates. Colloid Surf. A-Physicochem. Eng. Asp. 2019, 577, 509-516. [CrossRef] 
23. Zou, L.; Wang, H.; Zhu, X.; Ding, Y.; Liao, Q. Active effect of super-hydrophobicity on droplet nucleate boiling. Int. J. Heat Mass Transf. 2020, 157. [CrossRef]

24. Faraz, M.; Ansari, M.Z.; Khare, N. Synthesis of nanostructure manganese doped zinc oxide/polystyrene thin films with excellent stability, transparency and super-hydrophobicity. Mater. Chem. Phys. 2018, 211, 137-143. [CrossRef]

25. Li, C.; Sun, Y.; Cheng, M.; Sun, S.; Hu, S. Fabrication and characterization of a $\mathrm{TiO}_{2}$ / polysiloxane resin composite coating with full-thickness super-hydrophobicity. Chem. Eng. J. 2018, 333, 361-369. [CrossRef]

26. Lv, D.; Fang, N.; Zhang, W. A PDMS modified polyurethane/Ag composite coating with super-hydrophobicity and low infrared emissivity. Infrared Phys. Technol. 2020, 108. [CrossRef]

27. Betar, B.O.; Alsaadi, M.A.; Chowdhury, Z.Z.; Aroua, M.K.; Mjalli, F.S.; Dimyati, K.; Hindia, M.N.; Elfghi, F.M.; Ahmed, Y.M.; Abbas, H.F. Bimetallic Mo-Fe Co-Catalyst-Based Nano-Carbon Impregnated on PAC for Optimum Super-Hydrophobicity. Symmetry 2020, 12, 1242. [CrossRef]

28. Saharudin, K.A.; Sreekantan, S.; Basiron, N.; Chun, L.K.; Kumaravel, V.; Abdullah, T.K.; Ahmad, Z.A. Improved superhydrophobicity of eco-friendly coating from palm oil fuel ash (POFA) waste. Surf. Coat. Technol. 2018, 337, 126-135. [CrossRef]

29. Sri, K.A.; Deeksha, P.; Deepika, G.; Nishanthini, J.; Hikku, G.S.; Shilpa, A.S.; Jeyasubramanian, K.; Murugesan, R. Superhydrophobicity: Mechanism, fabrication and its application in medical implants to prevent biomaterial associated infections. $J$. Ind. Eng. Chem. 2020, 92, 1-17. [CrossRef]

30. Wang, N.; Wang, Q.; Xu, S.; Qu, L.; Shi, Z. Robust superhydrophobic wood surfaces with mechanical durability. Colloid Surf. A-Physicochem. Eng. Asp. 2021, 608. [CrossRef]

31. Dányádi, L.; Móczó, J.; Pukánszky, B. Effect of various surface modifications of wood flour on the properties of PP/wood composites. Compos. Part. A Appl. Sci. Manuf. 2010, 41, 199-206. [CrossRef]

32. Sharma, G.; Kumar, A.; Naushad, M.; Al-Misned, F.A.; El-Serehy, H.A.; Ghfar, A.A.; Sharma, K.R.; Si, C.; Stadler, F.J. Graft Copolymerization of Acrylonitrile and Ethyl Acrylate onto Pinus Roxburghii Wood Surface Enhanced Physicochemical Properties and Antibacterial Activity. J. Chem. 2020, 2020. [CrossRef]

33. Hansmann, C.; Weichslberger, G.; Gindl, W. A two-step modification treatment of solid wood by bulk modification and surface treatment. Wood Sci. Technol. 2005, 39, 502-511. [CrossRef]

34. Yang, L.; Liu, H. Effect of a Combination of Moderate-Temperature Heat Treatment and Subsequent Wax Impregnation on Wood Hygroscopicity, Dimensional Stability, and Mechanical Properties. Forests 2020, 11, 920. [CrossRef]

35. Liu, X.; Wu, Z.; Zhang, J. The Effects of Heating Treatment on the Tensile Properties of Palm Petioles Fiber. Bioresources 2017, 12, 1335-1343. [CrossRef]

36. Epmeier, H.; Westin, M.; Rapp, A. Differently modified wood: Comparison of some selected properties. Scand. J. For. Res. 2011, 19, 31-37. [CrossRef]

37. Cheng, L.; Ren, S.; Lu, X. Application of Eco-Friendly Waterborne Polyurethane Composite Coating Incorporated with Nano Cellulose Crystalline and Silver Nano Particles on Wood Antibacterial Board. Polymers 2020, 12, 407. [CrossRef] [PubMed]

38. Xiong, X.; Ma, Q.; Yuan, Y.; Wu, Z.; Zhang, M. Current situation and key manufacturing considerations of green furniture in China: A review. J. Clean Prod. 2020, 267. [CrossRef]

39. El-Hefny, M.; Salem, M.Z.M.; Behiry, S.I.; Ali, H.M. The Potential Antibacterial and Antifungal Activities of Wood Treated with Withania somnifera Fruit Extract, and the Phenolic, Caffeine, and Flavonoid Composition of the Extract According to HPLC. Processes 2020, 8, 113. [CrossRef]

40. Ashmawy, N.A.; Salem, M.Z.M.; El Shanhorey, N.; Al-Huciail, A.A.; Ali, H.M.; Behiry, S.I. Eco-friendly Wood-biofungicidal and Antibacterial Activities of Various Coccoloba uvifera L. Leaf Extracts: HPLC Analysis of Phenolic and Flavonoid Compounds. Bioresources 2020, 15, 4165-4187. [CrossRef]

41. Chen, R.; Zhang, Y.; Xie, Q.; Chen, Z.; Ma, C.; Zhang, G. Transparent Polymer-Ceramic Hybrid Antifouling Coating with Superior Mechanical Properties. Adv. Funct. Mater. 2021. [CrossRef]

42. Ivask, A.; Bondarenko, O.; Jepihhina, N.; Kahru, A. Profiling of the reactive oxygen species-related ecotoxicity of $\mathrm{CuO} \mathrm{ZnO} \mathrm{TiO}_{2}$, silver and fullerene nanoparticles using a set of recombinant luminescent Escherichia coli strains: Differentiating the impact of particles and solubilised metals. Anal. Bioanal. Chem. 2010, 398, 701-716. [CrossRef]

43. Zhang, F.; Lee, M.H.; Huang, Y.X.; Keller, A.A.; Majumdar, S.; Cervantes-Aviles, P.; Tang, X.X.; Yin, S.Q. Effective water disinfection using magnetic barium phosphate nanoflakes loaded with Ag nanoparticles. J. Clean Prod. 2019, 218, 173-182. [CrossRef]

44. Yang, J.; Chen, Y.; Jia, X.; Li, Y.; Wang, S.; Song, H. Wood-Based Solar Interface Evaporation Device with Self-Desalting and High Antibacterial Activity for Efficient Solar Steam Generation. Acs. Appl. Mater. Interfaces 2020, 12, 47029-47037. [CrossRef]

45. Kubo, A.L.; Capjak, I.; Vrcek, I.V.; Bondarenko, O.M.; Kurvet, I.; Vija, H.; Ivask, A.; Kasemets, K.; Kahru, A. Antimicrobial potency of differently coated 10 and $50 \mathrm{~nm}$ silver nanoparticles against clinically relevant bacteria Escherichia coli and Staphylococcus aureus. Colloid Surf. B-Biointerfaces 2018, 170, 401-410. [CrossRef]

46. Duan, X.; Liu, S.; Huang, E.; Shen, X.; Wang, Z.; Li, S.; Jin, C. Superhydrophobic and antibacterial wood enabled by polydopamineassisted decoration of copper nanoparticles. Colloid Surf. A-Physicochem. Eng. Asp. 2020, 602. [CrossRef]

47. Gao, L.; Lu, Y.; Li, J.; Sun, Q. Superhydrophobic conductive wood with oil repellency obtained by coating with silver nanoparticles modified by fluoroalkyl silane. Holzforschung 2016, 70, 63-68. [CrossRef]

48. Park, C.; Na, J.; Han, M.; Kim, E. Transparent Electrochemical Gratings from a Patterned Bistable Silver Mirror. ACS Nano 2017, 11, 6977-6984. [CrossRef] 
49. Chen, X.; Zhang, B.; Xie, L.; Wang, F. MWCNTs polyurethane sponges with enhanced super-hydrophobicity for selective oil-water separation. Surf. Eng. 2020, 36, 651-659. [CrossRef]

50. Cai, T.; Shen, X.; Huang, E.; Yan, Y.; Shen, X.; Wang, F.; Wang, Z.; Sun, Q. Ag nanoparticles supported on MgAl-LDH decorated wood veneer with enhanced flame retardancy, water repellency and antimicrobial activity. Colloid Surf. A-Physicochem. Eng. Asp. 2020, 598, 9. [CrossRef]

51. Ou, J.; Zhao, G.; Wang, F.; Li, W.; Lei, S.; Fang, X.; Siddiqui, A.R.; Xia, Y.; Amirfazli, A. Durable Superhydrophobic Wood via One-Step Immersion in Composite Silane Solution. Acs. Omega 2021, 6, 7266-7274. [CrossRef]

52. Zhang, L.; Lin, N.; Zou, J.; Lin, X.; Liu, Z.; Yuan, S.; Yu, Y.; Wang, Z.; Zeng, Q.; Chen, W.; et al. Super-hydrophobicity and corrosion resistance of laser surface textured AISI 304 stainless steel decorated with Hexadecyltrimethoxysilane (HDTMS). Opt. Laser Technol. 2020, 127. [CrossRef]

53. Tien, H.; Huang, Y.; Yang, S.; Wang, J.; Ma, C. The production of graphene nanosheets decorated with silver nanoparticles for use in transparent, conductive films. Carbon 2011, 49, 1550-1560. [CrossRef]

54. Yang, C.; Cui, S.; Weng, Y.; Wu, Z.; Liu, L.; Ma, Z.; Tian, X.; Fu, R.; Chu, P.K.; Wu, Z. Scalable superhydrophobic T-shape micro/nano structured inorganic alumina coatings. Chem. Eng. J. 2021, 409. [CrossRef]

55. Song, P.; Wang, C.; Sun, Y.; Bousquet, A.; Tomasella, E. Broadband and Wide-Temperature-Range Thermal Emitter with Super-Hydrophobicity Based on Oxidized High-Entropy Film. Acs. Appl. Mater. Interfaces 2020, 12, 4123-4128. [CrossRef]

56. Huang, L.; Ling, L.; Su, J.; Song, Y.; Wang, Z.; Tang, B.; Westerhoff, P.; Ye, R. Laser-Engineered Graphene on Wood Enables Efficient Antibacterial, Anti-Salt-Fouling, and Lipophilic-Matter-Rejection Solar Evaporation. ACS Appl. Mater. Interfaces 2020, 12, 51864-51872. [CrossRef] [PubMed]

57. Misuri, F.; Marri, L. Antibacterial activity of wood distillate from residual virgin chestnut biomass. Eur. J. Wood Wood Prod. 2020. [CrossRef]

58. Wang, N.; Wan, Q.; Xu, S.; Luan, J. Flexible films with wrinkled micro-nano hierarchical structures having stable superhydrophobicity under external loading. J. Mater. Sci. 2020, 55, 9623-9637. [CrossRef]

59. Nagarajappa, G.B.; Pandey, K.K. UV resistance and dimensional stability of wood modified with isopropenyl acetate. J. Photochem. Photobiol. B 2016, 155, 20-27. [CrossRef]

60. Yue, D.; Lin, S.; Cao, M.; Lin, W.; Zhang, X. Fabrication of transparent and durable superhydrophobic polysiloxane $/ \mathrm{SiO}_{2}$ coating on the wood surface. Cellulose 2021, 28, 3745-3758. [CrossRef]

61. Chen, H.; Zhang, W.; Wang, X.; Wang, H.; Wu, Y.; Zhong, T.; Fei, B. Effect of alkali treatment on wettability and thermal stability of individual bamboo fibers. J. Wood Sci. 2018, 64, 398-405. [CrossRef]

62. Liu, X.; Timar, M.C.; Varodi, A.M. An investigation of accelerated temperature-induced ageing of four wood species: Colour and FTIR. Wood Sci. Technol. 2017, 51, 357-378. [CrossRef] 